\title{
MODAL SOSIAL DALAM MENUMBUHKAN DAN MENDIFUSIKAN INOVASI PERTANIAN HORTIKULTURA SEBAGAI BASIS PENGEMBANGAN EKONOMI LOKAL STUDI KASUS: KABUPATEN BANDUNG DAN BANDUNG BARAT
}

Social Capital in Innovation Diffusion and Development of Horticulture Sector as a Basis for Local Economic Development

Case Study: Bandung and West Bandung Districts

\section{Dewi Sawitri Tjokropandojo ${ }^{1}$, Ainna Aqmarini ${ }^{1}$, Dika Fajri Fiisabiilillah ${ }^{1}$}

\begin{abstract}
Abstrak: Tulisan ini mengeksplorasi pengaruh modal sosial dalam menumbuhkan dan mendifusikan inovasi pertanian hortikultura sebagai basis pengembangan ekonomi lokal. Pendekatan studi yang digunakan adalah pendekatan studi kasus kualitatif, yang didukung oleh teknik analisis pencocokan pola hubungan teoritis dan pola hubungan empiris. Temuan studi ini menunjukkan bahwa modal sosial petani pada kegiatan ekonomi yang relatif lebih tinggi dibanding pada kegiatan sosial dapat menumbuhkan inovasi secara mandiri, lebih meluas dan perkembangannya lebih maju. Modal sosial petani yang relatif tinggi pada kegiatan ekonomi pun dapat mempermudah dan mempercepat proses difusi inovasi serta pendifusiannya berkembang lebih luas, tidak terbatas pada kelompok atau petani tertentu saja. Sementara itu, modal sosial masyarakat petani pada kegiatan sosial yang relatif lebih tinggi dibandingkan pada kegiatan ekonomi tidak menunjukkan adanya dorongan dalam menumbuhkan inovasi secara mandiri dan perkembangan inovasi. Karakteristik modal sosial tersebut juga tidak mempermudah pendifusian inovasi dan proses difusi hanya terjadi pada kelompok petani yang terbatas. Kesimpulannya adalah keberadaan Modal Sosial Petani yang tinggi pada kegiatan ekonomi merupakan kunci Keberlanjutan Pengembangan Ekonomi Lokal Berbasis Pertanian, melalui Pertumbuhan dan Difusi Inovasi Pertanian.
\end{abstract}

Kata kunci: difusi inovasi, kegiatan ekonomi, kegiatan sosial, modal sosial.

Abstract: This paper explores the impact of social capital in developing and diffusing an innovation of horticulture sector as a basis for Local Economic Development. This study uses a qualitative approach, which is conducted by a comparison analysis of the relationship pattern between theoretical foundation and empirical evidence. The finding shows that social capital among the farmers in the economic activity is relatively higher than social activity. This capital can independently grow, develop, and expand innovations among farmers' networks. The high shared

\footnotetext{
${ }^{1}$ Perencanaan Wilayah dan Kota, Sekolah Arsitektur, Perencanaan dan Pengembangan Kebijakan (SAPPK), ITB
} 
values among farmers in economic activity can also accelerate and catalyze an innovation diffusion process and, thus, it can grow onto among social class within rural community. Meanwhile, the same pattern does not replicate in the social activity, since it cannot independently stimulate the development of innovation diffusion. It also cannot catalyze such process and, thus, it only establishes among certain groups within the community. The conclusion is the high presence of social capital among farmers in the economic activity is an essential key to sustain the agriculturebased local economic development, through a process of innovation diffusion in the horticulture sector.

Key words: economic activity, innovation diffusion, social activity, social capital

\section{PENDAHULUAN}

Seiring meningkatnya tantangan Pengembangan Wilayah, sebagai salah satu Konsep Pengembangan Wilayah yang lebih menekankan pada Sumberdaya Lokal, Local Economic Development (LED) telah berkembang menjadi Sustainable Local Economic Development. Blakely (2010) menyatakan bahwa LED dicapai ketika suatu Standar Kehidupan Komunitas dapat dipelihara dan ditingkatkan melalui suatu proses Pengembangan Manusia dan Fisik yang didasarkan pada prinsip-prinsip keadilan dan keberlanjutan. Definisi tersebut mempunyai elemen penting yaitu, pengembangan ekonomi menentukan suatu Standar Hidup Minimal bagi semua dan meningkatkan standart ini sepanjang waktu, pengembangan ekonomi mengurangi Ketimpangan, mencakup ketimpangan antar kelompok masyarakat dan kelompok dalam ruang wilayah, serta pengembangan ekonomi meningkatkan dan mendorong Penggunaan Sumberdaya dan Produksi yang berkelanjutan.

Pertanian merupakan sektor kegiatan ekonomi yang sangat potensial dan sesuai sebagai Basis Pengembangan Ekonomi Lokal (LED). Karakateristik kegiatan pertanian yang tidak mengambil dan menghabiskan sumberdaya alam sesuai dengan Konsep Pengembangan Ekonomi untuk meningkatkan dan mendorong Penggunaan Sumberdaya dan Produksi yang Berkelanjutan. Kegiatan Pertanian juga mampu menyerap tenaga kerja dalam jumlah besar serta kemampuan dan ketrampilan yang dibutuhkan untuk ikut serta dalam kegiatannya secara umum dikuasi oleh masyarakat, khususanya Masyarakat Agraris, seperti Masyarakat Indonesia pada umumnya. Dengan karakteristik tersebut, Kegiatan Pertanian juga sesuai sebagai basis Pengembangan Ekonomi yang mengurangi Ketimpangan. Karakteristik Kegiatan Pertanian ini dapat dibandingkan dengan Kegiatan Ekonomi lainnya khususnya Industri. Kegiatan Industri, khususnya Industri Besar dan Sedang hanya dapat berkembang di lokasi tertentu, dengan kebutuhan tenaga kerja yang spesifik, sehingga tidak seluruh masyarakat dapat terlibat di dalamnya, sehungga potensial menyebabkan ketimpangan antar kelompok masyarakat dan antar ruang wilayah.

Meskipun Kegiatan Pertanian sangat potensial sebagai basis LED, karena sesuai sebagai kegiatan ekonomi yang mampu Mengurangi Ketimpangan dan kegiatan ekonomi yang meningkatkan dan mendorong Penggunaan Sumberdaya dan Produksi yang berkelanjutan, namun pada sisi lain Kegiatan Pertanian juga mempunyai kelemahan sebagai basis LED terkait dengan kemampuannya sebagai penjamin tercapainya Standar Hidup Minimal bagi semua dan meningkatnya standar ini sepanjang waktu. Apabila kegiatan pertanian masih bertumpu pada kegiatan yang masih bersifat tradisional, maka kegiatan pertanian belum dapat memberikan kemakmuran pada petani, karena nilai Tambah yang rendah dan kebutuhan lahan yang luas.

Padahal seiring dengan pertumbuhan jumlah penduduk, maka kebutuhan akan lahan untuk permukiman maupun pertanian semakin besar sedangkan luas lahan tidak bertambah. Keadaan tersebut menjadikan kegiatan pertanian tidak dapat menjadi sumber kehidupan yang memenuhi standar minimal, karena lahan garapan petani semakin lama semakin menyempit dan nilai tambah hasil kegiatan pertanian per luasan lahan tidak meningkat. 
Keadaan di atas menunjukkan bahwa apabila Kegiatan Pertanian ke depan masih bertumpu pada kegiatan yang bersifat tradisional, maka kegiatan pertanian tidak dapat seutuhnya sebagai basis LED.

Permasalahan ketidakmampuan Kegiatan Pertanian untuk mengangkat petani mencapai standar hidup minimal terjadi secara umum di wilayah perdesaan di Indonesia. Bila keadaan ini tidak ditanggulangi, maka akan banyak penduduk perdesaan di Indonesia tidak akan berminat lagi menekuni bidang pertanian yang akan berakibat pada turunnya ketahanan pangan, serta besarnya migrasi penduduk desa ke kota, sehingga semakin membebani kota atau harus mengadu nasib di negeri orang, sehingga menurunkan martabat bangsa. Pada kasus Pertanian Hortikultura, persoalannya semakin rumit. Pertanian hortikultura merupakan kegiatan ekonomi dengan rentang kegiatan produksi dan pemasaran dalam jangka waktu yang relatif pendek. Hal ini berkaitan dengan karakteristik hasil pertanian hortikultura yang usia masa penggunaannya pendek, karena masa kesegaran sayur-mayur yang relatif singkat setelah dipanen, sehingga harus cepat dipasarkan. Dengan karakteristik komoditas pertanian itu, maka kegiatan pertanian ini semakin sulit untuk mampu meberikan kesejahteraan pada petani.

Pada kasus Sentra Produksi Pertanian Hortikultura Kabupaten Bandung dan Bandung Barat, meskipun hasil produksi pertanian hortikultura Sentra Produksi ini memiliki peluang pasar yang besar, karena berada pada lokasi yang strategis yang berdekatan dengan kota besar yaitu Bandung dan Jakarta, namun hasilnya belum mampu memberikan kemakmuran pada petani. Studi yang telah dilakukan Lufiandi pada tahun 1999 menunjukkan bahwa para petani hortikultura di Kabupaten Bandung bagian selatan belum mampu mengelola kegiatan pertanian secara optimal. Beberapa hal yang menyebabkan ketidakoptimalan tersebut antara lain karena semakin menyempitnya lahan pertanian garapan petani, juga karena para petani memiliki tingkat ketergantungan yang tinggi terhadap para tengkulak akibat kekhawatiran para petani jika produk pertanianya tidak dapat dipasarkan, karena masa kesegarannya yang terbatas. Implikasi yang terjadi adalah dengan produktivitas yang terbatas dari waktu ke waktu, para petani tidak memiliki posisi tawar yang baik terhadap para tengkulak sehingga margin keuntungan yang diterima pun sangat kecil.

Agar kegiatan pertanian, khususnya pertanian hortikultura, sepenuhnya mampu menjadi basis LED maka Inovasi dalam kegiatan pertanian hortikultura merupakan suatu keharusan. Secara umum, Inovasi merupakan sebuah ide, praktek atau objek yang dipahami sebagai sesuatu yang baru oleh masing-masing individu atau unit pengelola lainnya (Rogers, 1995). Terkait dengan persoalan yang dihadapi dalam kegiatan pertanian hortikultura, keberadaan ide, praktek atau obyek baru yang mampu mengoptimalkan kegiatan pertanian hortikultura sebagai basis LED, khususnya dalam mencapai standar hidup minimal petani, sangat dibutuhkan. Dengan kata lain temuan-temuan baru yang berbeda dan yang memperbaiki apa yang sudah ada sebelumnya sangat dibutuhkan dalam kegiatan pertanian hortikultura, untuk memaksimalkan pendapatan petani dengan mempertimbangkan adanya kendala yang ada berupa karakteristik komoditas dan semakin sempitnya lahan. Untuk memaksimalkan pendapatan petani, ide, praktek atau obyek baru harus muncul mulai dari kegiatan pra produksi, produksi sampai kegiatan pemasaran.

Dalam menciptakan inovasi dibutuhkan pengetahuan dan kemampuan yang cukup tinggi serta wawasan yang luas dari para petani. Inovasi dapat tercipta dari individu atau kelompok petani. Masyarakat petani Indonesia, secara umum mempunyai pengetahuan, kemampuan dan wawasan yang sangat terbatas, sehingga sulit diharapkan munculnya inovasi dari individu petani. Ketika pengetahuan, kemampuan dan wawasan yang dimiliki oleh individu petani telah bergabung dengan yang dimiliki oleh petani lain yang berada dalam satu kelompok, maka akan menjadi kekuatan yang besar untuk menciptakan inovasi. Kekuatan ini dimungkinan ketika ada "Modal Sosial" petani. Modal Sosial merupakan semua sumberdaya yang seorang pelaku dapat kerahkan atau ambil manfaatnya karena 
kelekatannya dalam suatu jaringan relasi dengan pelaku lain (Janssens, 2007). Beberapa komponen modal sosial dari beberapa sumber (Ostrom dan Ahn, 2003; Burt, 2000; Colemann, 1988) adalah kepercayaan, jaringan, dan juga norma yang berlaku. Oleh karena itu, di dalam Modal Sosial termasuk suatu kapasitas individu untuk menghimpun bantuan atau suatu kemampuan kolektif untuk menghasilkan atau memanfaatkan suatu iklim kepercayaan (Castiglione, 2008). Keberadaan modal sosial akan memudahkan para petani berbagi pengetahuan, kemampuan dan wawasan, sehingga memudahkan munculnya inovasi. Disamping itu, keberadaan modal sosial juga akan memudahkan terjadinya difusi inovasi, karena hilangnya batas-batas atau sekat-sekat diantara petani. Difusi inovasi merupakan suatu proses bagaimana sebuah inovasi disampaikan melalui saluran komunikasi pada waktu tertentu terhadap sekelompok masyarakat dalam suatu sistem sosial yang di dalamnya terdapat proses keputusan inovasi (Rogers, 1995). Selain tumbuhnya inovasi pertanian, agar inovasi bermafaat secara luas untuk petani lain dalam meningkatkan standar hidupnya, maka inovasi perlu didifusikan kepada petani lain.

Makalah ini dituliskan berdasarkan hasil penelitian yang bertujuan untuk menentukan pengaruh Modal Sosial Petani dalam Menumbuhkan dan Mendifusikan Inovasi Pertani Hortikulura. Manfaat dari penelitian ini adalah untuk memahami keberadaan dan peran modal sosial petani sebagai dasar untuk menumbuhkan dan mendifusikan inovasi pertanian di wilayah sentra pertanian hortikultura sebagai basis LED. Penelitian dilakukan di dua sentra produksi pertanian Hortikulura di Propinsi Jawa Barat, yaitu di Kabupaten Bandung dan Kabupaten Barat.

\section{Modal Sosial Petani dalam Menumbuhkan dan Mendifusikan Inovasi}

Sumberdaya yang ada dalam Modal Sosial sebagai hasil kelekatannya dalam suatu jaringan relasi antar pelaku merupakan modal yang sangat kuat untuk menumbuhkan dan mendifusikan inovasi, ketika pengetahuan, kemampuan dan wawasan individu terbatas (Laursen, dkk, 2012; Akcomak dan Weel, 2009; Landry, dkk, 2002; Cooke dan Wills, 1999; Fountain, 1998). Dengan adanya modal sosial berarti individu mempunyai kapasitas untuk menghimpun bantuan dan mempunyai kemampuan kolektif untuk memanfaatkan iklim kepercayaan. Kapasitas untuk saling membantu yang didukung oleh iklim kepercayaan antar individu dalam suatu komunitas memudahkan untuk menghimpun pengetahuan, kemampuan dan wawasan individu menjadi pengetahuan, kemampuan dan wawasan komunitas yang sangat kuat untuk mendorong tumbuhnya inovasi dalam komunitas tersebut. Iklim kepercayaan yang baik, menghilangkan sekat-sekat diantara individu di dalam komunitas, sehingga menimbulkan sifat mudah berbagi di antara anggota komunitas, termasuk berbagi hasil inovasi.

Modal Sosial merupakan sumberdaya yang ada pada individu-individu sebagai hasil dari adanya relasi dan interaksi, hubungan timbal baik dan kerjasama antara individuindividu dalam kelompok yang didasarkan pada kepercayaan (Castiglione, 2008; Carpenter, 2004; Putnam, 1993; Fukuyama,1995). Cukup banyak manfaat yang dimiliki oleh modal sosial, baik dalam kehidupan sosial maupun ekonomi. Diantara manfaatnya yang dimiliki modal sosial tersebut, banyak manfaat yang terkait dalam menumbuhkan dan mendifusikan inovasi. Seperti telah disampaikan di depan bahwa inovasi yang berhubungan dengan kemunculan ide atau gagasan baru, praktek atau tindakan baru serta obyek atau barang baru di bidang pertanian sangat dibutuhkan untuk meningkatkan nilai tambah dan mengatasi keterbatasan lahan, yang pada akhirnya akan meningkatkan pendapatan petani untuk mencapai standar hidup minimum. Untuk menghasilkan inovasi yang berguna untuk meningkatkan kesejahteraan petani, diperlukan rasa tanggung jawab dan solidaritas serta koordinasi dan kesatuan para petani untuk mencapai tujuan bersama, yaitu memperbaiki nasib mereka. Disamping itu, juga diperlukan sinergisitas, kemauan berbagi gagasan dan 
keahlian diantara para petani, sehingga kuantitas dan kualitas pengetahuan, kemampuan dan wawasan setiap individu petani semakin meningkat, pada akhirnya para petani secara kolektif akan mampu menghasilkan ide dan praktek baru di dalam kegiatan pertanian, dari mulai pra produksi, proses produksi hingga pemasaran, serta mampu menghasilkan komoditas baru yang mempunyai produktivitas tinggi, kualitas yang baik, harga yang baik dan mempunyai pasar yang luas. Hubungan tersebut menunjukkan adanya peran sumberdaya yang ada dalam modal sosial untuk menumbuhkan inovasi di bidang pertanian.

Dalam mencapai kesejahteraan seluruh, Inovasi pertanian yang telah dihasilkan tidak hanya terbatas dimanfaatkan oleh petani yang menemukan inovasi tersebut, tetapi juga harus dinikmati oleh petani lain secara luas. Oleh karena itu diperlukan suatu proses bagaimana sebuah inovasi disampaikan kepada masyarakat petani, atau harus terjadi difusi inovasi pertanian pada masyarakat petani. Menurut Roger (1995), difusi inovasi meliputi sejumlah tahapan yang terdiri dari, adanya pengetahuan individu atau kelompok yang mampu memahami dan menjaga eksistensi dari suatu fungsi pekerjaan, persuasi individu atau kelompok memiliki sikap yang menguntungkan ataupun tidak menguntungkan terhadap terjadinya inovasi, keputusan individu atau kelompok untuk mengikat dan mengadaptasi inovasi menjadi tindakan yang nyata atau menolaknya, implementasi pemanfaatan ide inovasi oleh individu atau kelompok dalam kegiatan, dan konfirmasi yang dilakukan individu atau kelompok terhadap keputusan pengimplementasian inovasi yang telah dilakukan, apakah inovasi tersebut akan tetap dilanjutkan atau justru dihentikan karena dapat memicu konflik atau sebagainya.

Pada proses difusi inovasi ada pihak pemberi dan penerima inovasi, bergantung pada kategori pengadopsi inovasi (Robertson, 1967). Kategori pemberi dan penerima inovasi adalah inovator, pengadopsi awal, mayoritas publik awal, mayoritas publik akhir, kaum tertinggal (Rogers, 2002). Hal ini Difusi terjadi apabila pihak pemberi bersedia menyebarkan inovasi yang dihasilkannya, sedang pihak penerima mampu dan mau menerima inovasi. Kesediaan pemberi untuk mendifusikan inovasi yang dihasilkan bergantung pada keberadaan rasa tanggungjawab dan solidaritas, kemauan berbagi gagasan dan keahlian, dan kesatuan anggota kelompok untuk mencapai tujuan bersama. Kesedian penerima untuk mampu menerima inovasi tidak lepas dari pengetahuan, kemampuan dan wawasan yang saling dibagi dalam diantara anggota kelompok, sedangkan kemauan untuk menerima inovasi bergantung pada kepercayaan setiap individu akan manfaat diterima dan digunakannya inovasi bagi dirinya dan kelompok. Hubungan tersebut menunjukkan adanya peran sumberdaya yang ada dalam modal sosial untuk mendifusikan inovasi di bidang pertanian.

\section{METODE}

Identifikasi Pengaruh Modal Sosial Petani dalam Menumbuhkan dan Mendifusikan Inovasi Pertanian Hortikulura didekati dengan mencari hubungan antara Keberadaan Modal Sosial Petani dengan Keberadaan Inovasi dalam Pertanian Hortikultura serta Difusinya. Keberadaan Modal Sosial Petani dilihat dari komponen-komponen pembentuk sumberdaya tersebut yaitu terkait dengan kelekatan sosial dan kepercayaan, sedang keberadaan Inovasi dilihat dari komponen -komponen pembaharuan terkait dengan gagasan, praktek dan produk, selanjutnya Difusi inovasi dilihat dari komponen-komponen proses penyebaran inovasi, yang terkait dengan saluran komunikasi dan waktu. Sesuai dengan karakteristik informasi yang detail dan komplek terkait dengan modal sosial dan inovasi serta difusinya, maka Pendekatan Penelitian yang digunakan adalah Pendekatan kualitatif, yaitu pendekatan studi kasus. Studi kasus merupakan suatu pendekatan yang digunakan untuk menjelaskan suatu fenomena yang kompleks, kontemporer dan terkait dengan konteks kehidupan nyata (Yin, 1994). 


\section{Proposisi Penelitian}

Hubungan antara keberadaan modal sosial petani dan keberadaan inovasi dalam pertanian hortikultura dan difusinya secara teoritis diungkapkan dalam proposisi didasarkan teori-teori yang mengungkapkan kegunanaan sumberdaya Modal Sosial terkait dalam perkembangan dan pendifusian inovasi, sebagai terlihat dalam tabel 1 berikut.

Tabel 1. Proposisi Hubungan Modal Sosial dengan Perkembangan dan Pendifusian Inovasi

\begin{tabular}{ll}
\hline \multicolumn{1}{c}{ Proposisi } & \multicolumn{1}{c}{ Dukungan Teori } \\
\hline Modal sosial yang baik cenderung menumbuhkan & Modal Sosial memudahkan koordinasi dan kerjasama \\
inovasi secara mandiri & yang saling menguntungkan, sehingga akan \\
& meningkatkan kuantitas dan kulitas modal intelektual \\
& yang disebar luaskan, selanjutnya menghasilkan \\
inovasi dan meningkatkan kemudahan menerima hal & baru (Fukuyama, 1995, Hartarto 1999, Serageldin dan \\
& Grootaert, 2000). \\
Modal sosial yang baik cenderung mempermudah & Rasa saling percaya, menghasilkan sinergi atau \\
dan mempercepat proses difusi inovasi di dalam & interaksi yang lebih baik dan solidaritas kelompok \\
maupun di luar kelompok & sehingga anggota kelompok akan mau berbagi \\
& gagasan dan keahlian pada anggota lain ( Belllah, \\
& 1991, Raka, 2003) \\
\hline
\end{tabular}

\section{Lokasi Studi}

Lokasi studi yang dipilih berada di Kabupaten Bandung dan Kabupaten Bandung Barat berdasarkan kriteria sebagai berikut:

- Sentra pertanian hortikultura

Sentra maju, yang dicirikan dengan jenis produksi terdiversifikasi dan memiliki pasar yang luas

- Pada lokasi di Kabupaten Bandung terpilih Desa Cisondari, Kecamatan Pasirjambu karena merupakan salah satu sentra pertanian hortikultura di wilayah tersebut. Jenis produk yang dihasilkan juga cukup banyak yaitu lebih dari 30 item serta pangsa pasar yang cukup luas, mencakup pasar lokal, pasar induk, supermarket di dalam maupun ke luar kota.

- Sedangkan, lokasi terpilih di Kabupaten Bandung Barat adalah Desa Cibodas, Kecamatan Lembang yang juga merupakan salah satu sentra pertanian hortikultura di wilayahnya. Jenis produk yang dihasilkan sangat banyak yaitu lebih dari 50 item dan pangsa pasar yang sangat luas, mencakup pasar lokal, pasar induk, supermarket di dalam maupun ke luar kota serta pasar ekspor.

\section{Pengumpulan dan Analisis Data}

Pengumpulan data dilakukan melalui survai data primer dengan teknik wawancara mendalam (in depth interview) pada responden kunci, yang mampu menjelaskan keberadaan modal sosial petani dan keberadaan inovasi dan difusinya di dalm kegiatan pertanian hortikultura mulai dari petani besar, petani kecil sampai petani gurem. Penentuan responden dilakukan dengan menggunakan teknik pengambilan sampel purposif dan snowball.

Proses analisis dalam penelitian ini dilakukan dengan metode analisis deskriptif kualitatif terhadap berbagai informasi yang diperoleh dari informan kunci untuk mengungkapkan keberadaan modal sosial petani dan keberadaan inovasi yang diciptakan oleh para petani holtikultura dan melacak proses difusi inovasinya. Hubungan antara keberadaan modal sosial petani dan keberadaan inovasi dalam pertanian hortikultura dan difusinya dianalisis dengan teknik pencocokan pola, yaitu mencocokkan antara pola 
hubungan teoritis, yang telah menjadi proposisi dengan pola hubungan empiris (Yin, 1994). analisis yang akan digunakan dalam merumuskan model pengembangan kerja sama antar daerah adalah analisis data kualitatif dengan metode analisis utama analisis isi transkrip wawancara dan analisis deskriptif data sekunder. Proses analisis dalam penelitian ini menggunakan proses induktif, yaitu penelusuran teori umum berdasarkan pengamatan di lapangan yang kemudian menghasilkan suatu kesimpulan. Teori yang akan dikembangkan dalam penelitian ini adalah teori biaya transaksi menurut Feiock (2005). Data hasil wawancara yang diperoleh kemudian akan dianalisis menggunakan metode analisis data kualitatif (qualitative data analysis). Dalam proses analisis dilakukan coding, yaitu proses identifikasi dan pengorganisasian tema dalam data kualitatif dan penjabaran kode serta penggunaannya yang bertujuan untuk mereduksi data dan menginterpretasikan makna dari data-data yang didapatkan dengan mengorganisasikannya berdasarkan kode-kode yang ditetapkan (Hay, 2010). Penilaian alternatif model kerja sama menggunakan metode Multi Criteria Analysis dan dilakukan oleh peneliti sebagai bahan pertimbangan kepada stakeholders pengambil keputusan. Proses penilaian dilakukan secara triangulasi dengan mempertimbangkan literatur yang berlaku serta hasil wawancara yang telah dilakukan. Triangulasi dilakukan karena peneliti masih belum berpengalaman untuk menilai sehingga diperlukan kerangka acuan logis yang dapat dipercaya untuk mendukung penilaian (judgement).
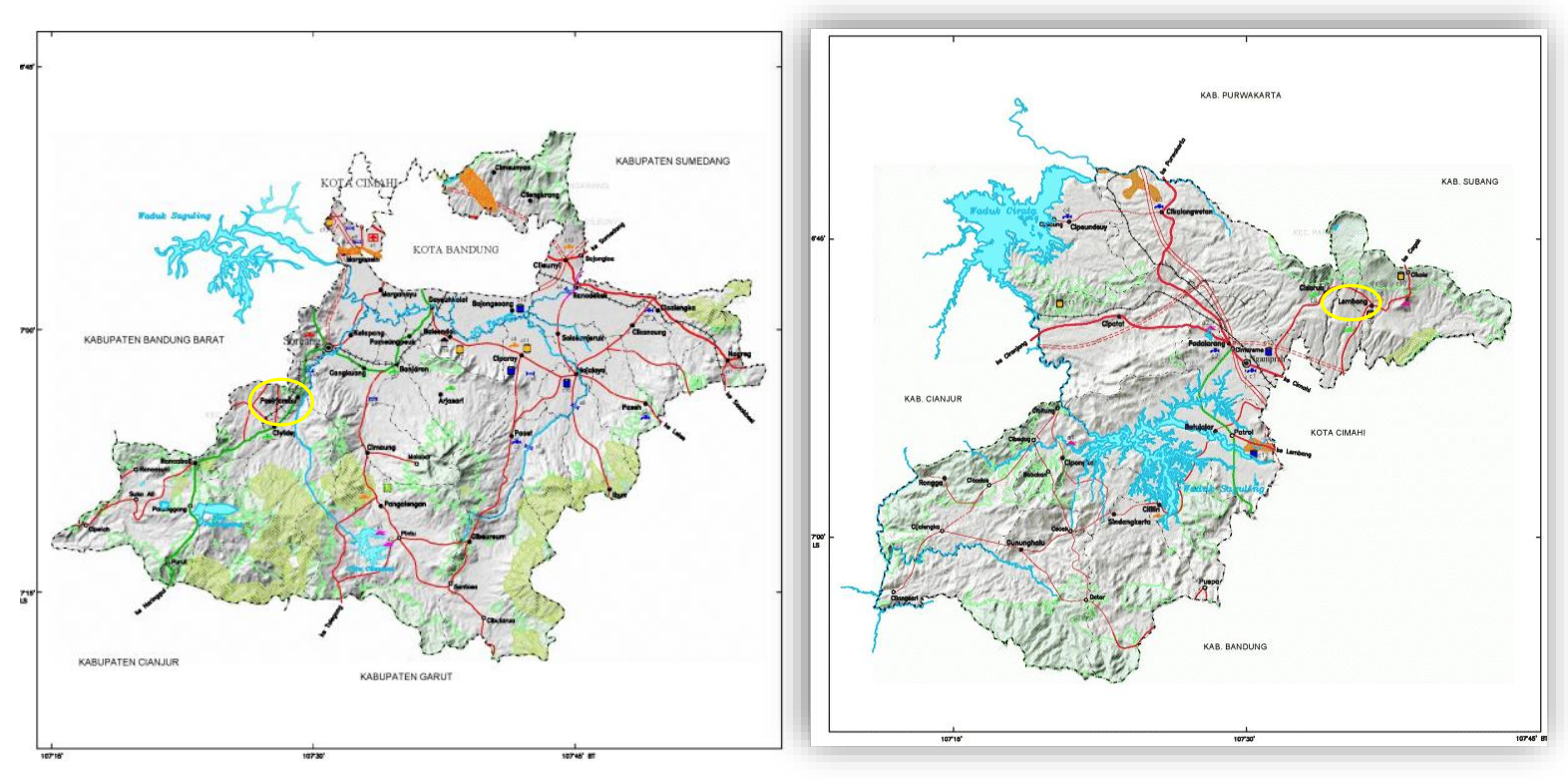

Sumber: http://loketpeta.pu.go.id/.

Gambar 1. Peta Orientasi Kab. Bandung (kiri) dan Kab. Bandung Barat (kanan) 


\section{HASIL DAN DISKUSI}

\section{Modal Sosial Petani di Desa Kasus}

Dalam menumbuhkan inovasi diperlukan keberadaan modal sosial petani yang kuat, baik yang diterapkan dalam kegiatan ekonomi maupun kegiatan sosial. Oleh karena itu, identifikasi komponen modal sosial yang dimiliki oleh masyarakat petani di kedua lokasi dibedakan menjadi dua, yaitu modal sosial di dalam kegiatan ekonomi pertanian masyarakatnya dan modal sosial di dalam kegiatan sosial warga desa. Sesuai dengan komponen pembentuk sumberdaya Modal Sosial yang telah dikemukakan sebelumnya, dalam penelitian ini keberadaan Modal Sosial dilihat dari: (1) Partisipasi; (2) Sikap Saling Peduli; (3) Kerjasama; (4) Hubungan Timbal Bali dan (5) Kepercayaan, baik yang diterapkan dalam kegiatan ekonomi maupun kegiatan sosial.

Tabel 2. Modal Sosial Petani Dalam Kegiatan Ekonomi dan Sosial di Kabupaten Bandung dan Kabupaten Bandung Barat

\begin{tabular}{|c|c|c|}
\hline $\begin{array}{c}\text { Komponen } \\
\text { Modal Sosial }\end{array}$ & Desa Cibodas-Lembang & Desa Cisondari-Pasirjambu \\
\hline Partisipasi & $\begin{array}{llr}\text { - } & \text { Adanya partisipasi } & \text { dalam } \\
\text { program/kegiatan ekonomi dan } & \text { sosial } \\
\text { yangada } & & \\
\text { Motivasi } \quad \text { keikutsertaan } & \text { pada } \\
\text { program/kegiatan ekonomi berdasarkan } & \\
\text { kesadaran dan tanpa paksaan terbatas } \\
\text { pada petani besar dan petani gurem } \\
\text { Motivasi keikutsertaan pada } \\
\text { program/kegiatan sosial berdasarkan } \\
\text { kesadaran dan tanpa paksaan }\end{array}$ & $\begin{array}{l}\text { - } \text { Partisipasi dalam program/kegiatan } \\
\text { ekonomi terbatas pada petani besar saja } \\
\text { - } \text { Adanya keikutsertaan dalam kegiatan } \\
\text { - } \text { Tidak ada motivasi untuk ikutserta dalam } \\
\text { program/kegiatan ekonomi yang ada } \\
\text { Motivasi keikutsertaan pada } \\
\text { program/kegiatan sosial berdasarkan } \\
\text { kesadaran dan tanpa paksaan }\end{array}$ \\
\hline $\begin{array}{l}\text { Sikap Saling } \\
\text { Peduli }\end{array}$ & $\begin{array}{l}\text { - Adanya pengetahuan tentang keadaan } \\
\text { kerabat yang mengalami kesulitan dalam } \\
\text { kegiatan ekonomi dan sosial } \\
\text { - Adanya keinginan yang kuat untuk } \\
\text { membantu meringankan beban orang lain } \\
\text { dalam kegiatan ekonomi dan sosial }\end{array}$ & $\begin{array}{l}\text { - Pengetahuan tentang keadaan kerabat } \\
\text { yang sedang mengalami kesulitan dalam } \\
\text { kegiatan ekonomi terbatas pada petani } \\
\text { besar dan petani kecil } \\
\text { - Adanya pengetahuan keadaan kerabat } \\
\text { dalam kegiatan sosial } \\
\text { Keinginan yang kuat untuk membantu } \\
\text { orang lain dalam kegiatan ekonomi } \\
\text { terbatas pada petani besar dan petani } \\
\text { kecil } \\
\text { Adanya keinginan yang kuat untuk } \\
\text { membantu orang lain dalam kegiatan } \\
\text { sosial }\end{array}$ \\
\hline Kerjasama & $\begin{array}{l}\text { - Adanya kesadaran pencapaian tujuan } \\
\text { bersama dalam kegiatan ekonomi pada } \\
\text { petani besar, petani kecil, dan petani } \\
\text { gurem } \\
\text { Adanya kesadaran pencapaian tujuan } \\
\text { bersama lintas petani secara lebih luas, } \\
\text { tidak hanya terjadi pada kelompok yang } \\
\text { memiliki kegiatan produksi bersama } \\
\text { Kurangnya kesadaran pencapaian tujuan } \\
\text { bersama dalam kegiatan sosial } \\
\text { Keterbukaan kondisi satu sama lain dalam } \\
\text { kegiatan ekonomi terbatas pada petani } \\
\text { besar dan petani gurem } \\
\text { Adanya keterbukaan kondisi lintas petani, } \\
\text { terutama mengenai } \\
\text { penentuan harga produk } \\
\text { Kurangnya keterbukaan terhadap kondisi } \\
\text { satu sama lain dalam kegiatan sosial }\end{array}$ & $\begin{array}{l}\text { - Kesadaran pencapaian tujuan bersama } \\
\text { dalam kegiatan ekonomi terbatas pada } \\
\text { petani besar, petani gurem dan buruh tani } \\
\text { Kesadaran pencapaian tujuan bersama } \\
\text { lintas petani terbatas pada kelompok } \\
\text { yang memiliki kegiatan produksi bersama } \\
\text { Adanya kesadaran untuk mencapai } \\
\text { tujuan bersama dalam kegiatan sosial }\end{array}$ \\
\hline
\end{tabular}




\begin{tabular}{|c|c|c|}
\hline $\begin{array}{c}\text { Komponen } \\
\text { Modal Sosial }\end{array}$ & Desa Cibodas-Lembang & Desa Cisondari-Pasirjambu \\
\hline $\begin{array}{l}\mathrm{Hu} \\
\text { Tim }\end{array}$ & 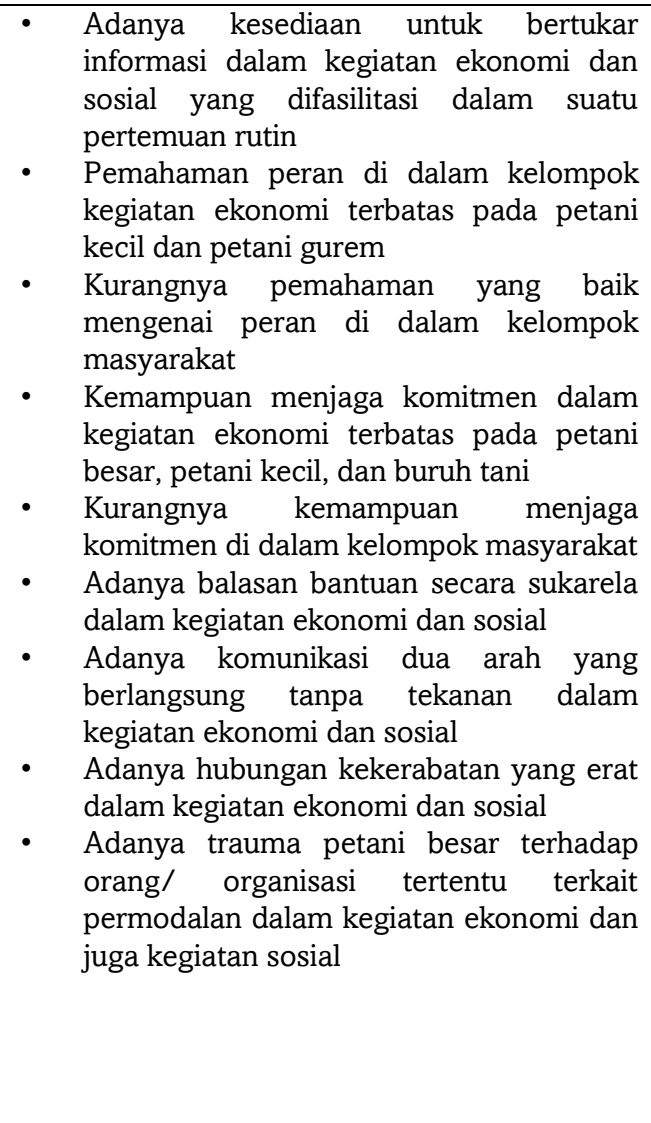 & $\begin{array}{l}\text { - Adanya kesediaan untuk bertukar } \\
\text { informasi dalam kegiatan ekonomi dan } \\
\text { sosial yang difasilitasi dalam suatu } \\
\text { pertemuan rutin } \\
\text { Pemahaman peran di dalam kelompok } \\
\text { kegiatan ekonomi terbatas pada petani } \\
\text { besar dan buruh tani organik } \\
\text { Adanya pemahaman yang baik } \\
\text { mengenai peran di dalam kelompok } \\
\text { masyarakat } \\
\text { Kemampuan menjaga komitmen dalam } \\
\text { kegiatan ekonomi terbatas pada petani } \\
\text { besar organik } \\
\text { Tidak ada komitmen di dalam kegiatan } \\
\text { sosial. } \\
\text { Adanya balasan bantuan secara sukarela } \\
\text { dalam kegiatan ekonomi dan sosial } \\
\text { Adanya komunikasi dua arah yang } \\
\text { berlangsung tanpa tekanan dalam } \\
\text { kegiatan ekonomi dan sosial } \\
\text { Adanya hubungan kekerabatan yang erat } \\
\text { dalam kegiatan ekonomi dan sosial } \\
\text { Adanya trauma petani besar, petani kecil } \\
\text { dan petani gurem terhadap } \\
\text { orang/organisasi tertentu terkait } \\
\text { permodalan dan bantuan pertanian } \\
\text { dalam kegiatan ekonomi } \\
\text { Ketiadaan perasaan trauma terhadap } \\
\text { orang/organisasi tertentu dalam } \\
\text { kegiatan sosial }\end{array}$ \\
\hline & $\begin{array}{l}\text { Adanya kemauan untuk meminjamkan } \\
\text { uang/barang kepada orang lain dalam kegiatan } \\
\text { ekonomi \& sosial: } \\
\text { - Tidak ada kebiasaan menitipkan amanah } \\
\text { kepada orang lain dalam kegiatan } \\
\text { ekonomi } \\
\text { Adanya perasaan aman untuk menitipkan } \\
\text { amanah kepada orang lain dalam kegiatan } \\
\text { bermasyarakat, seperti menitipkan rumah }\end{array}$ & $\begin{array}{l}\text { Adanya kemauan untuk meminjamkan } \\
\text { uang/barang kepada orang lain dalam } \\
\text { kegiatan ekonomi \& sosial: } \\
\text { - Perasaan aman menitipkan amanah } \\
\text { kepada orang lain dalam kegiatan } \\
\text { ekonomi terbatas pada petani kecil dan } \\
\text { petani gurem } \\
\text { Adanya perasaan aman menitipkan } \\
\text { amanah kepada orang lain dalam } \\
\text { kegiatan sosial }\end{array}$ \\
\hline $\mathrm{N}$ & $\begin{array}{l}\text { - Pemahaman yang sama mengenai } \\
\text { perilaku dalam kegiatan ekonomi terbatas } \\
\text { pada petani besar saja } \\
\text { Adanya pemahaman yang sama mengenai } \\
\text { perilaku dalam kegiatan sosial } \\
\text { bermasyarakat } \\
\text { Adanya pemikiran yang sama mengenai nilai } \\
\text { kebenaran yang berlaku di masyarakat dalam } \\
\text { kegiatan sosial }\end{array}$ & $\begin{array}{l}\text { - Pemahaman yang sama mengenai } \\
\text { perilaku dalam kegiatan ekonomi } \\
\text { terbatas pada petani besar saja } \\
\text { Adanya pemahaman yang sama } \\
\text { mengenai perilaku dalam kegiatan sosial } \\
\text { bermasyarakat } \\
\text { Adanya pemikiran yang sama mengenai nilai } \\
\text { kebenaran yang berlaku di masyarakat dalam } \\
\text { kegiatan sosial }\end{array}$ \\
\hline
\end{tabular}

Sumber: Hasil Analisis, 2013

Berdasarkan hasil analisis yang dilakukan dikedua lokasi, ditemukan bahwa pada dasarnya Desa Cibodas-Lembang dari berbagai komponen mengindikasikan mempunyai modal sosial dalam kegiatan ekonomi yang lebih unggul dibandingkan dengan Desa Cisondari-Pasirjambu. Sebaliknya Desa Cisondari-Pasirjambu mempunyai modal sosial dalam kegiatan sosial yang lebih kuat daripada Desa Cibodas-Lembang. 


\section{Inovasi Pertanian di Desa Kasus}

Sesuai dengan pengertian Inovasi yang disampaikan oleh Rogers, dalam penelitian ini untuk memahami keberadaan inovasi di dalam bidang pertanian hortikultura di desa-desa kasus ditinjau dari tiga indikator, yaitu (1) adanya ide atau gagasan baru; (2) adanya objek atau produk baru; dan (3) adanya praktek baru yang terjadi dalam kegiatan pertanian hortikultura. Inovasi yang tumbuh dalam kegiatan pertanian hortikultura di kedua desa kasus, ditinjau dari inovasi yang dihasilkan oleh tiga kategori petani, yaitu petani besar, petani kecil, dan petani gurem.

Tabel 3. Inovasi Pertanian Berdasarkan Klasifikasi Petani di Kabupaten Bandung dan Kabupaten Bandung Barat

\begin{tabular}{|c|c|c|c|}
\hline Komponen & \multicolumn{3}{|c|}{ Komponen Inovasi } \\
\hline & Petani Besar & Petani Kecil & Petani Gurem \\
\hline \multicolumn{4}{|c|}{ Desa Cibodas- Lembang } \\
\hline $\begin{array}{l}\text { Ide/g } \\
\text { baru }\end{array}$ & $\begin{array}{l}\text { - } \begin{array}{l}\text { Pengembangan komoditi } \\
\text { dan produk olahan }\end{array} \\
\text { - } \begin{array}{l}\text { Penggunaan teknologi } \\
\text { modern }\end{array} \\
\text { - } \\
\text { Penciptaan pasar sendiri }\end{array}$ & $\begin{array}{lll}\text { - } & \begin{array}{l}\text { Pengembangan } \\
\text { budidaya }\end{array} & \text { teknik } \\
\text { - } & \begin{array}{l}\text { Pemasaran ke } \\
\text { modern }\end{array}\end{array}$ & $\begin{array}{lll}\text { - } & \begin{array}{l}\text { Pengembangan } \\
\text { budidaya }\end{array} \\
\text { - } & \begin{array}{l}\text { Penggunaan } \\
\text { modern }\end{array} \\
\text { - } & \begin{array}{l}\text { Pemasaran kelogi } \\
\text { modern }\end{array}\end{array}$ \\
\hline $\begin{array}{l}\text { Objek/ } \\
\text { produk baru }\end{array}$ & $\begin{array}{ll}\text { - } & \text { Komoditi sayuran } \\
\text { eksklusif (sayuran Jepang) } \\
\text { - } \\
\text { Teknologi mulsa plastik, } \\
\text { sistem irigasi, dan cara } \\
\text { penyemaian } \\
\text { - } \\
\text { Pemasaran mandiri }\end{array}$ & $\begin{array}{l}\text { - Penggunaan mesin/alat } \\
\text { pascapanen }\end{array}$ & $\begin{array}{l}\text { - Pupuk dan obat ramah } \\
\text { lingkungan }\end{array}$ \\
\hline Prakte & 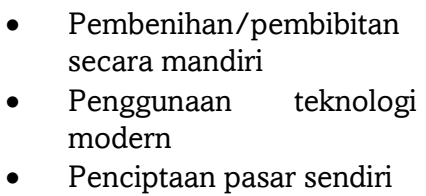 & $\begin{array}{l}\text { - Penggunaan mesin/alat } \\
\text { pascapanen }\end{array}$ & $\begin{array}{l}\text { tan pupuk dan } \\
\text { nah lingkungan }\end{array}$ \\
\hline $\begin{array}{l}\text { Ide/g } \\
\text { baru }\end{array}$ & $\begin{array}{ll}\text { - } & \text { Sistem permodalan } \\
\text { - } & \text { Pembentukan organisasi } \\
& \text { pascapanen } \\
\text { - } & \text { Pengembangan produk } \\
\text { olahan } \\
\text { - } & \text { Pemasaran mandiri } \\
\end{array}$ & 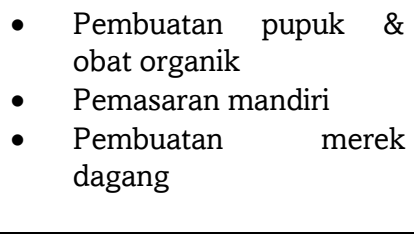 & 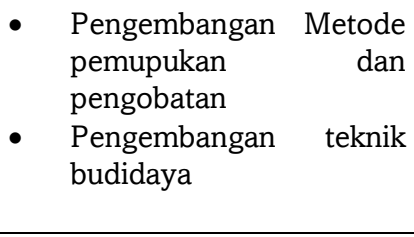 \\
\hline \multicolumn{4}{|c|}{ Desa Cisondari- Pasirjambu } \\
\hline $\begin{array}{l}\text { Objek/ } \\
\text { produk baru }\end{array}$ & $\begin{array}{ll}\text { - } & \text { Sayuran organik } \\
\text { - } & \text { Produk olahan } \\
\text { - } & \text { Pemasaran ke pasar } \\
\text { modern }\end{array}$ & $\begin{array}{ll}\text { - } & \text { Pupuk \& obat organik } \\
\text { - } & \text { Merek dagang } \\
\text { - } & \text { Section pascapanen }\end{array}$ & 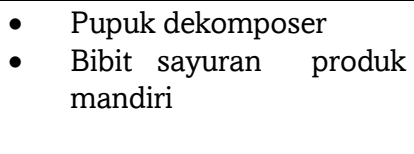 \\
\hline Praktek baru & $\begin{array}{l}\text { - Pembudidayaan Sayuran } \\
\text { organik } \\
\text { - } \quad \text { Pembuatan pupuk limbah } \\
\text { ternak (pupuk kandang) } \\
\text { - } \quad \begin{array}{l}\text { Menjalin Kemitraan } \\
\text { dengan Pasar Modern }\end{array} \\
\end{array}$ & 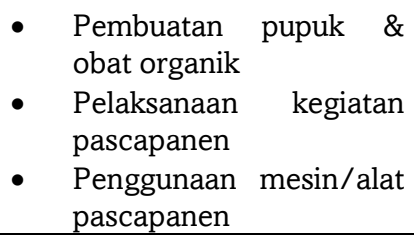 & $\begin{array}{llr}\text { - } & \begin{array}{l}\text { Pembuatan } \\
\text { organik }\end{array} & \text { pupuk } \\
\text { - } & \begin{array}{l}\text { Pengembangan } \\
\text { budidaya }\end{array} & \text { teknik } \\
\text { - } & \begin{array}{l}\text { Pelaksanaan } \\
\text { pascapanen }\end{array} & \text { kegiatan } \\
\end{array}$ \\
\hline
\end{tabular}

Sumber: Hasil Analisis, 2013

Berdasarkan komponen di atas, terlihat bahwa petani besar di Desa Cibodas-Lembang melakukan beberapa inovasi, terutama pengembangan komoditas sayuran eksklusif, yaitu sayuran Jepang, untuk memenuhi pasar restoran Jepang, diikuti inovasi dalam pemasaran dalam bentuk penciptaan pasar sendiri, sehingga tidak bergantung kepada tengkulak.

Sementara di Desa Cisondari-Pasirjambu, inovasi yang dihasilkan oleh petani besar adalah pengembangan sayuran organik dan produk olahan, diikuti inovasi pemasaran 
produk ke pasar modern, sehingga juga tidak bergantung pada tengkulak. Inovasi pada Desa Cibodas-Lembang lebih "luas dan bebas" dibandingkan dengan inovasi yang terjadi di Desa Cisondari-Pasirjambu, baik dalam jenis komoditas maupun pemasaran.

Pada sisi lain, petani kecil dan petani gurem pada kedua desa tersebut juga menghasilkan inovasi, namun terbatas pada teknik budidaya dan belum diikuti dengan inovasi dalam pemasaran. Pada inovasi teknik budidaya petani kecil dan gurem di Desa Cibodas-Lembang lebih luas daripada di Desa Cisondari-Pasirjambu, karena desa ini hanya fokus pada tanaman organik, sedang dalam inovasi pemasaran kedua desa sama, yaitu masih berhenti pada gagasan saja. Dengan demikian, inovasi pemasaran hanya dapat dilakukan oleh petani besar.

\section{Difusi Inovasi Pertanian di Desa Kasus}

Sesuai dengan pengertian Difusi Inovasi yang dikemukakan Rogers, dalam penelitian ini pemahaman keberadaan difusi inovasi pertanian hortikultura di desa-desa kasus akan ditinjau dari dua indikator, yaitu (1) keberadaan difusi inovasi yang dilakukan pada waktu tertentu; dan (2) keberadaan difusi inovasi yang dilakukan melalui saluran komunikasi tertentu.

Tabel 4 Difusi Inovasi Pertanian Berdasarkan Klasifikasi Petani di Kabupaten Bandung dan Kabupaten Bandung Barat

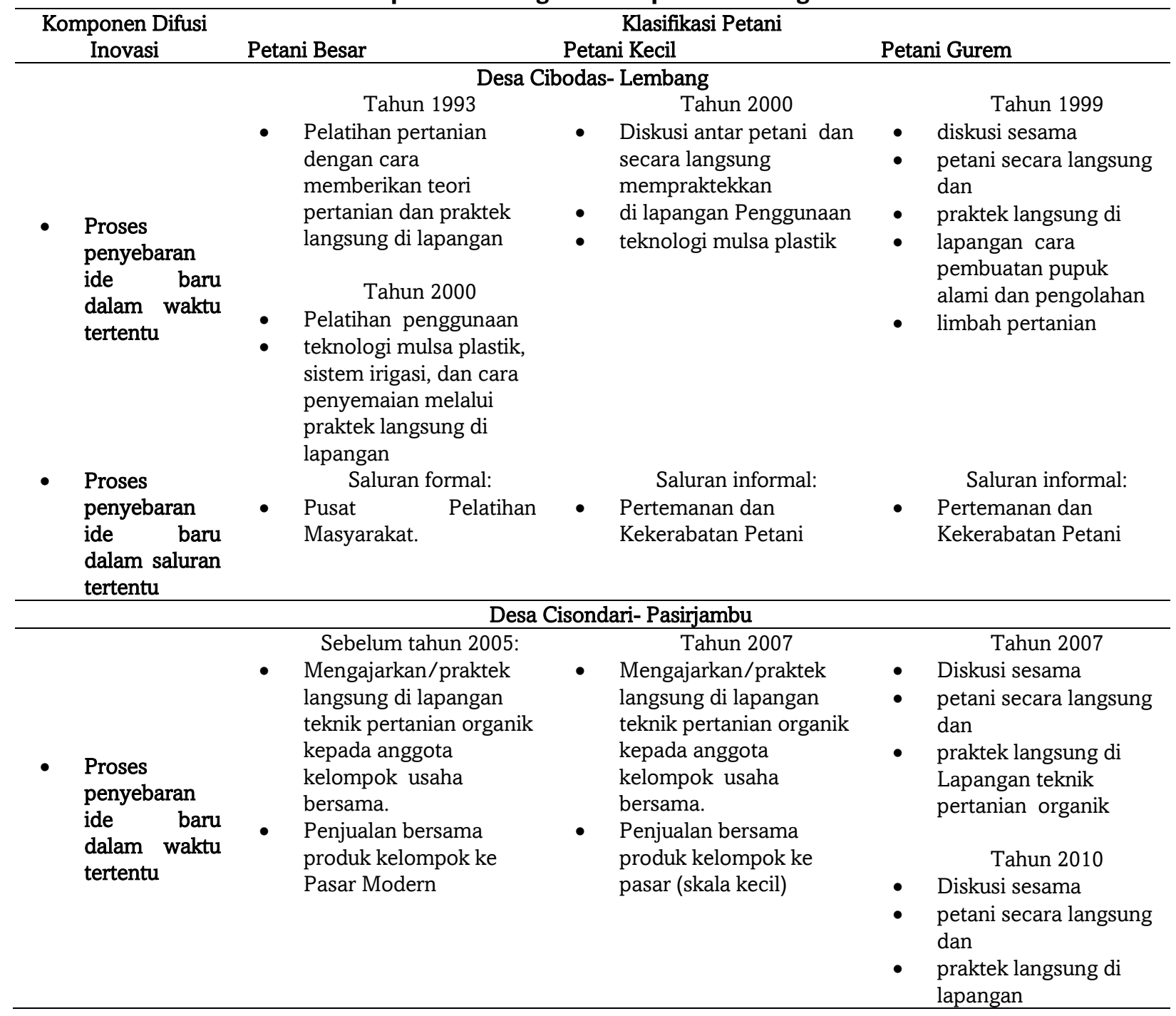




\begin{tabular}{|c|c|c|c|}
\hline \multirow{2}{*}{$\begin{array}{l}\text { Komponen Difusi } \\
\text { Inovasi }\end{array}$} & \multicolumn{3}{|c|}{ Klasifikasi Petani } \\
\hline & Petani Besar & Petani Kecil & Petani Gurem \\
\hline $\begin{array}{l}\text { - Proses } \\
\text { penyebaran } \\
\text { ide baru } \\
\text { dalam saluran } \\
\text { tertentu }\end{array}$ & $\begin{array}{l}\quad \text { Saluran informal: } \\
\text { - } \quad \text { Kelompok kegiatan } \\
\text { usaha produksi } \\
\text { bersama antar petani. }\end{array}$ & $\begin{array}{l}\quad \text { Saluran informal: } \\
\text { - Kelompok kegiatan } \\
\text { usaha produksi bersama } \\
\text { antar petani. }\end{array}$ & $\begin{array}{ll}\text { - } & \text { Teknik tumpangsari } \\
\text { tanaman } \\
\text { Saluran informal: } \\
\text { - } & \text { Pertemanan dan } \\
& \text { Kekerabatan Petani }\end{array}$ \\
\hline
\end{tabular}

Sumber: Hasil Analisis, 2013

Pada Desa Cisondari-Pasirjambu, diketahui bahwa penyebaran inovasi hanya terjadi sebatas pada pihak-pihak yang melakukan produksi bersama. Sementara di Desa CibodasLembang, difusi inovasi lebih terbuka dimana semua pihak bisa memproduksi sendiri setelah terjadinya pelatihan pertanian, sebagai saluran informasi yang bersifat formal. Pada umumnya saluran yang bersifat formal telah terjadi pada kelompok petani besar, sementara petani kecil dan petani gurem hanya menyalurkan difusi inovasi secara informal, melalui pertemanan dan kekerabatan.

\section{Hubungan Modal Sosial dengan Inovasi dan Difusi Inovasi}

Dalam proposisi menyebutkan bahwa modal sosial yang kuat cenderung akan menumbuhkan inovasi pertanian secara mandiri serta mempermudah dan mempercepat difusi inovasi tersebut di dalam maupun di luar kelompoknya.

Tabel 5. Hubungan Modal Sosial Dengan Tumbuhnya Inovasi dan Difusi Inovasi

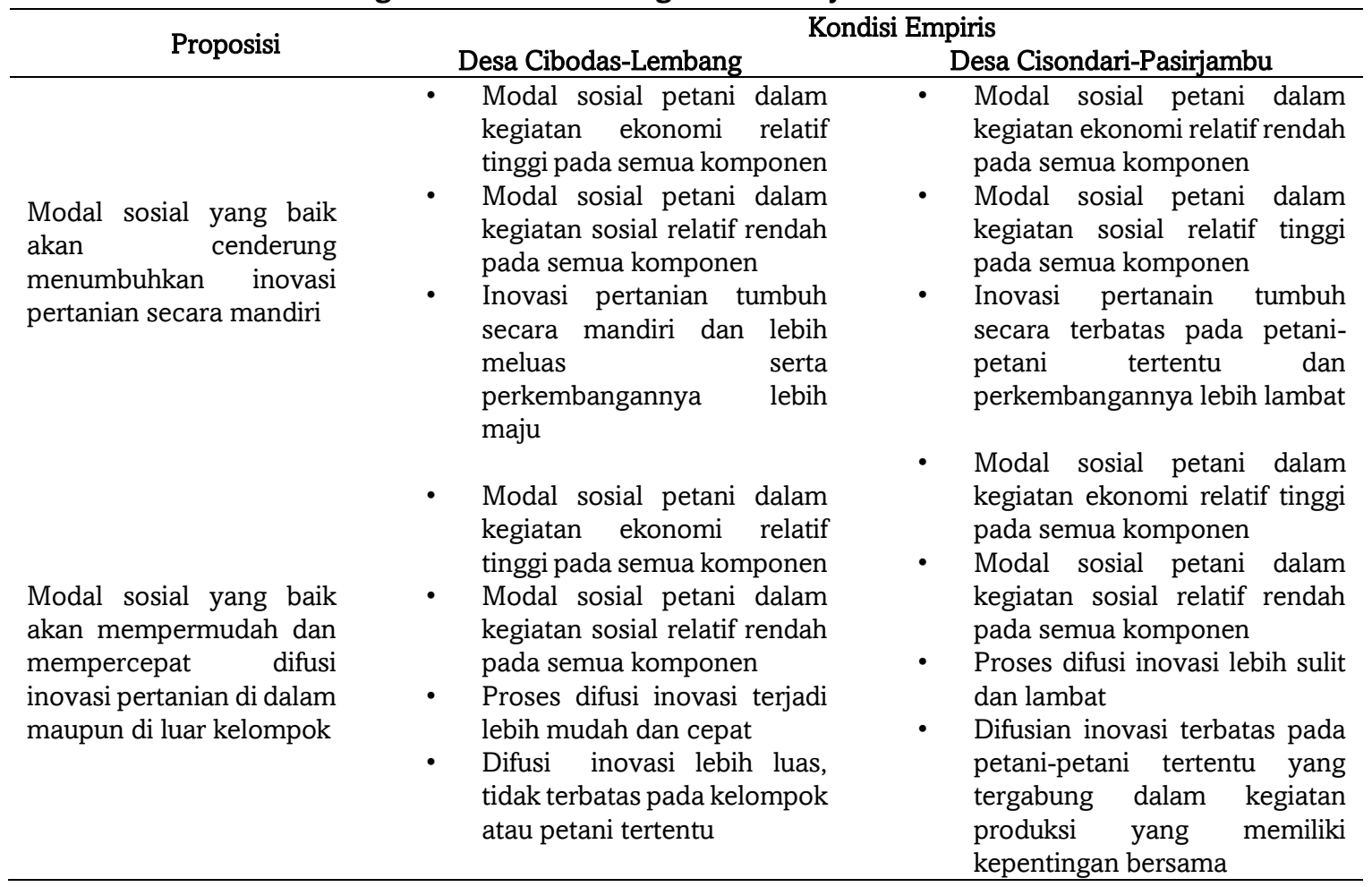

Sumber: Hasil Analisis, 2013

Pencocokkan antara antara hubungan keberadaan modal sosial dengan keberadaan inovasi teoritis dan empiris ditemukan bahwa keberadaan modal sosial yang kuat diterapkan di dalam kegiatan ekonomi mendukung proposisi, yaitu ketika modal sosial kuat akan diikuti dengan tumbuhnya inovasi pertanian secara mandiri yang berkembang dengan baik. 
Keberadaan modal sosial yang kuat diterapkan di dalam kegiatan sosial tidak mendukung proposi, yaitu ketika modal sosial yang kuat tidak diikuti dengan tumbuhnya inovasi pertanian secara mandiri yang berkembang baik.

Pencocokan antara hubungan keberadaan modal sosial dengan difusi inovasi teoritis dan empiris ditemukan bahwa keberadaan modal sosial yang kuat diterapkan di dalam kegiatan ekonomi mendukung proposisi, yaitu ketika modal sosial kuat akan diikuti dengan kemudahan dan kecepatan proses, serta keluasan difusi inovasi. Keberadaan modal sosial yang kuat diterapkan di dalam kegiatan sosial tidak mendukung proposi, yaitu ketika modal sosial yang kuat tidak diikuti dengan kemudahan dan kecepatan proses, serta keluasan difusi inovasi.

\section{KESIMPULAN}

Berdasarkan temuan di atas dapat disimpulkan bahwa Modal Sosial dalam kegiatan ekonomi atau kelekatan sosial dan kepercayaan masyarakat petani holtikultura dalam kegiatan ekonomi merupakan pendorong terjadinya munculnya gagasan, praktek dan produk baru serta penyebarannya ke seluruh petani, sehingga akan meningkatkan produktivitas petani.Modal sosial atau kelekatan sosial dan kepercayaan yang ada pada masyarakat petani tidak cukup hanya diterapkan dalam kegiatan sosial saja, tetapi harus diterapkan untuk kegiatan ekonomi juga, agar mampu menghasilkan inovasi dan difusinya, sehingga petani mampu mengembangkan kegiatan pertanian secara bersama dan mengatasi kendala-kendala yang dihadapinya, sehingga masyarakat petani dapat meningkatkan pendapatannya dan mencapai standard hidup minimal. Modal sosial dalam kegiatan sosial atau kelekatan sosial dan kepercayaan masyarakat petani holtikultura dalam kegiatan sosial tetap penting hadir bersama untuk mendukung munculnya gagasan, praktek dan produk baru serta penyebarannya ke seluruh petani. Modal Sosial Petani yang tinggi pada kegiatan ekonomi, yang tetap didukung oleh keberadaan modal sosial pada kegiatan sosial, merupakan kunci Keberlanjutan Pengembangan Ekonomi Lokal Berbasis Pertanian, melalui Pertumbuhan dan Difusi Inovasi Pertanian. Oleh karena itu, dapat disimpulkan bahwa modal sosial memiliki pengaruh terhadap penumbuhan dan pendifusian inovasi petani hortikultura. Modal sosial merupakan pendorong munculnya gagasan, praktek dan produk baru serta penyebarannya ke seluruh petani yang tetap perlu dipertahankan baik dalam kegiatan sosial maupun ekonomi. Hal ini akan berpengaruh pada keberlanjutan pengembangan ekonomi lokal berbasis pertanian. Sehingga, pertimbangan akan modal sosial dalam pengembangan kebijakan dan perencanaan pengembangan ekonomi lokal berbasis pertanian menjadi hal penting sebagai kunci keberhasilan kebijakan dan perencanaan kegiatan perdesaan berbasis pertanian.

\section{DAFTAR PUSTAKA}

Akcomak, I S., Weel, Bas (2009) Social Capital, Innovation and Growth: Evidence from Europe. European Economic Review, 53, 544-567.

Bellah, R. N., et al. (1991) Democracy Means Paying Attention, The Good Society. New York: Alfred A. Knopf Inc.

Blakely, Leigh (2010) Planning Local Economic Development: Theory and Practice. Sage Publication.

Burt, R. S., (2000) The Network Structure of Social Capital. Research in Organizational Behaviour, 22, 345-423.

Cainclli, G., Mancinclli, S., Mazzanti, M. (2007) Social Capital and Innnovation Dynamics in District-based Local Systems. The Journal of Socio-Economics, 36, 932-948.

Carpenter, J.P, et al. 2004. Social Capital an Trust in South-east Asian Cities, Urban Studies, 41(4), 853-874.

Castiglione, D (2008) The Handbook of Social Capital, Oxford Universy Press.

Coleman, J. S., (1988) Social Capital in the Creation of Human Capital. American Journal of Sociology, 94, S95S120. 
Talitha

Cooke, P. Wills, D. (1999) Small Firms, Social Capital, and the Enhancement of Business Performance Through Innovation Programmes. Small Business Economics, 13, 219-234.

Fountain, J E., (1998) Social Capital: Its Relationship to Innovation in Science and Technology. Science and Public Policy, 25(2), 103-115.

Fukuyama, F. (1995) Trust: The Social Virtues and Creation of Prosperity. New York: Free Press Paperbacks.

Hartanto, M. S. (1999) Peran Etika Dalam Bisnis Yang Berbekal Modal Maya, Studio Manajemen. Institut Teknologi Bandung.

Janssens, W., (2007) Social Capital and Cooperation: An Impact Evaluation of a Women's Empowerment Programme in Rural India. Amsterdam: Vrije Universiteit Amsterdam

Landry, R., Amara, N., Lamari, M. (2002) Does Social Capital Determine Innovation? To What Extent? Technological Forecasting \& Social Change, 69, 681-701.

Laursen, K., Masciarelli, F., Prencipe, A. (2012) Region Matter: How Localized Social Capital Affects Innovation and External Knowledge Acquistion. Organization Science, 23(1), 177-193.

Lufiandi. (1999) Kajian Pengembangan Sumber Daya Lokal Pertanian melalui Pendekatan Pemasaran Produk: Studi kasus pada Kecamatan Ciwidey dan Kecamatan Pasirjambu, Kabupaten Bandung. Tugas Akhir Jurusan Teknik Planologi, FTSP, ITB.

Ostrom, E., Ahn, T. K., (2003) A Social Science Perspective on Social Capital: Social Capital and Collective Action. Revista Mexicana De Sociologia, 65(1), 155-233.

Putnam, R. (1993) The Properous Community: Social Capital dan Community Life. The American Prospect 13 (1), 35-42.

Raka, Gede. (2003) Membangun Budaya Inovasi Untuk Tata Pemerintahan Yang Baik, Dalam Bidang Manajemen Perkotaan, Makalah Lokakarya Internasional Membangun Budaya Inovasi untuk Menuju Tata Pemerintahan yang Baik, Nusa Dua Bali, 10-13 Juni 2003.

Robertson, Thomas S. (1967). The Process of Innovation and the Diffusion of Innovation. American Marketing Association 31 (1), 14-19.

Rogers, Everett M. (2002) Diffusion of Preventive Innovations., Addictive Behaviors, 27, 989-993.

Rogers, Everett M. (1995) Diffusion of Innovation - Fifth Edition. New York: Free Press.

Sedyadi, Gema Satria. (2012) Dukungan Modal Sosial Terhadap Kelembagaan Pertanian Dalam Peningkatan Posisi Tawar Pada Sistem Tata Niaga (Studi Kasus: Kabupaten Karawang dan Kabupaten Subang). Tugas Akhir Program Studi Perencanaan Wilayah dan Kota ITB.

Serageldin, I. and Grootaert, C. (2000) Defining Social Capital: An Integrating View, 2000. In P. Dasgupta dan I. Serageldin (Ed.), Social Capital: A Multi Faceted Perspective, 40-57. Washington, DC: The World Bank.

Stimsoo, R.J., et al. 2009. Regional Economic Development: Analysis and Planning Srategy.

Yin, R.K. (1994) Case Study Research: Design and Methods. New Delhi: SAGE Publications. 